ORDINARY MEETING, JANUARY 3rd, 1879.

Prof. Morris, M.A., F.G.S., President, in the Chair.

The Donations received since the previous Meeting were announced.

The following was elected a Member of the Association :-

Lawrence Scate, Esq.

The following Paper was read:-

\title{
On the British Eocenes and their Deposition.
}

By J. Starkie Gardner, F.G.S.

The Eocenes of England are so familiar to every student of geology that it would appear but little remains to be said about them which has not been said alrealy, as well in a sketchy and popular form as in more scientific treatises. So carefully has their Fauna been worked out, and equally so the corresponding series in France, that it is rare indeed that any new form is added to the lists. Those who are familiar with the best known localities where fossils occur in greatest abundance-on the Hampshire, Isle of Wight, Sussex, and Kentish coasts-know that even the rarer treasures they come across are all known and described.

It is quite otherwise with the Flora, the British literature of which is most meagre. Although plant-remains are in all probability far more abundant and varied than those of animals, and possess in many respects, at the present time, a higher interest, we have to turn to the pages of French, Swiss, Austrian, German, Italian, American, and, indeed, to the works of every civilised country but our own, if we wish to learn anything respecting them. It is useless to enter into the variety of canses which have led to this state of things, but it is primarily due to that habit of caution and thought, and the desire to find a basis of solid fact, which distinguishes so many of the more important works of our countrymen. Hence English botanists have refused to determine plants upon material which is quite insufficient in most cases; and although the result has been that, in this particular line of research, foreigners have quite outstripped us, those who study the subject have cause 
to wish that they had themselves been imbued with some of the same spirit.

I propose to describe the British Eocenes, therefore, with especial regard to the floras they contain; and although it takes me over much ground that is not new to you, it is important that $I$ should do so, so that you may become aware of the absolutely certain data upon which the sequence assigned to the English Eocene Floras is based, and how definite is their position in the geological scale. Their comparatively exceptional value will then be fully realised. The composition of the various floras we shall scarcely glance at-that is not within the scope of the paper-but I wish especially to lay before you some speculations which have been induced in my mind through their presence, and the examination of them which I have already made. Their exact botanical determinations is work for the future, and Baron von Ettingshansen is engaged upon a preliminary examination of the fruits of Sheppey.

The age of the very localised beds on the continent in which most of the Tertiary and Cretaceous floras have been found, has in almost every instance been ascertained only approximately. The majority of them either lie upon far older rocks, or upon marine beds with which their deposition had no connection. In such cases the data required for the exact determination of their age are wholly wanting, and the ages were inferred from plant evidence alone. This, I am perfectly sure, has not hitherto been entitled to that credence which may become attached to it when more floras, as extensive and well defined in age as that of Oeningen, for example, shall have been described.

Debcription of Eocene Strata in Enqland.-The gap between the Cretaceous and Eoceneformations in Western Europe, upon which I have contributed a paper in the "Popular Science Review" for January 1879, is further increased in England by the absence of the lower members of the Eucene of France and Belgium.*

The Thanet Sands $\dagger$ are almost confined in England to the

* Hébert, "Ann. Soc. Geol.," Vol. iv.

+ These are widely spread over Picardy and Flanders as the Sables de Bracheux, and over Belginm as the I andénien inférieur. The three or four feet of and which fill in the eroded sarface of the Chalk, and rest upon the familiar green coated flints, have been thought to represent the series in Hampshire.-See Prestwich, Q. J. G. S., Vol. viii, p. 237; " Mem. Geol. Surv.," Vol. iv., pt.I., 55 ; and Hébert, l.c. 
eastern area of the London Basin, but with this and one other exception all the Lower and Middle Eocenes are represented at Alum Bay, and in consecutive order. They may, indeed, owing to their vertical position and the height and accessibility of the cliffs, all be studied within a space of a few hundred yards. I think, therefore, it will be most simple to describe each series of beds of the Alum Bay section separately, pointing out at the same time their extent and nature on the mainland. With this object, the principal features of Professor Prestwich's admirable sections both of Alum and Whitecliff Bay are reproduced, although modified to suit the somewhat different interpretation which $I$ have given to them. The section shows that the oldest Eocene deposit present, except perhaps the small patches of sand filling in the erosions in the Chalk, belong to the Woolwich and Reading series.

The equivalents of these in the Hants Basin are compact masses of more or less ferruginous, homogenous mottled clay, unfossiliferous with the single exception of traces of lignite. They are supposed to be of fluviatile origin, and derived from granite. It will be observed that the beds thin ont from a thickness of 160 feet at Whitecliff Bay to only $80^{\prime}$ at Alum Bay. This thinning continues west, so that at Studland Bay their presence is hardly perceptible. When we trace the corresponding beds from W. to $\mathrm{E}$. within the London Basin, we find-first mottled clays, like those of Hampshire, then beds of lignite and sand containing fresh and brackish water shells mingled with it, and finally that $\mathrm{E}$. of London the mottled clays disappear altogether, their place being taken by sands with estuarine shells.*

I would here parenthetically remark that throughout onr Eocenes fresh-water beds are far more developed in the west than in the east, and this holds good even when they are local or on a small scale.

The Olduaven Beds.-Although these do not occur in this basin they form a well recognised division in the London Basin. They consist wholly of beds of well-rolled flint shingle or fine sand. The fossils are intermediate in character between those of the London Clay and Woolwich and Reading series, a large proportion

* Very similar formations occur in the Paris Basin and in Belgium which are supposed to be of this age. They are known as the Argile plastique et lignites and the Landénien supérieur. 
coming from one or passing into the other; occasionally they are common to all three, and are estuarine and marine. The principal mass occur's in Kent, and the beds have not been traced in Hampshire nor on the Continent.

The London ChaY.-This is represented in the Isle of Wight, principally by compact brown clay with septaria.* Mr Prestwich assigns to it at Alum Bay, a thickness of a little less than 200 feet, placing the division just above No. 6 of his section. I think, however, it should be placed as high as No. 14, so as to include the succeeding 176 feet of marine sands. These so resemble the sulphuryellow grey sands, with seams of dark grey clay, intercalated at No. 5 between two masses of undoubted London Clay, as to be lithologically indistinguishable. Very similar sands are also intercalated between masses of true London Clay with septaria, at Whitecliff. They are, besides, totally unlike any of the Lower Bagshot Sands in the district, although they have hitherto been included with them, and are of marine, while the latter are of fresh-water origin. At Whitecliff it is 307 feet thick. In the London Basin this clay thickens eastwards, being 50 feet at Newbury, about 400 to 440 feet at London, and 480 at Sheppey and on the coast opposite. It has been divided into distinct zones, marking the progressive increase in the depth of the sea. Towards Harwich it has a considerable N.E. extension, and it is traced across the Channel to Calais, and thence to Belgium, as the Argille d'Ypres. It never, however, extended over the Paris area.

The Lower Bagshot Beds.-These are well exposed at Alum Bay, although but 73 feet thick, according to my grouping. $\dagger$ They there consist principally of bright coloured, sometimes mottled, sharp, quartzose sands, the prevailing colours of which are white, yellow and deep red. These enclose here and elsewhere basins or patches of almost pure white pipe-clay, one of which, present at Alum Bay, has yielded the flora. The beds vary in character within very short distances. For example, there is a thick seam of deepred coarse sand near the top of the cliff, and no trace of it at the base. Whilst the beds are seen at Studland and round Corfe to thicken very considerably west, they thin rapidly east, and appear to

* Althongh it contains only the shallow-water Mollusca, peculiar in the London Basin to the lower section of the London Clay, it was probably contemporary with its upper section there.

+249 feet, according to the Geological Survey. 
change their character, being, perhaps, represented at Whitecliff Bay by some of the 98 feet of "broad-striped sands, of various shades of yellow, passing upwards into nearly white sand," No. 5 of Prestwich's section. Beds of this age may be distinguished from the overlying strata, if unfossiliferous by the total absence of flint in them, by the brilliant hues or pure white of much of the clays, and by their coarse quartzose sands. They are also traceable over the western area of the London Basin. East of Windsor the fresh-water beds, like the older mottled clays, are replaced by beds entirely made up of rolled flint and shingle derived from the Chalk.*

The Middle Bagshot Beds.-These, according to the extent which I assign to them, comprise the whole of the Bracklesham, the Bournemouth, and the Bovey Tracey deposit, and the Middle and so-called Upper Bagshot Beds of the London Basin. I have, it will be seen, enriched this portion of the series in a rather wholesale way, throwing into them not only a great part of the so-called Lower and Upper Bagshots, but the only piece of Miocene which we had in England. I have elsewhere stated my views upon these questions, $\dagger$ and time does not permit me to enter into them bere. There is no need to describe the Bracklesham Beds. They are partly or entirely the marine equivalents of the Bournemouth and Bovey fresh-water beds, and of the littoral Boscombe and Hengistbury Head beds. They cover a limited area, and are present to but a slight extent in the more $S$. and $W$. portions of the London Basin. Their fauna is peculiar to them in England, but extends far over France in the Calcaire grossier and other beds. They can, everywhere I believe, be recognised, in the absence of fossils, by the presence of green grains.

The Bournemouth Beds are divisible into three, the Lower one fresh-water, the others marine. The fresh-water beds are best represented on the coast from Poole Harbour to Bournemouth, and at Alum Bay by Nos. 19 to 24 of Prestwich's section, or 241 feet of sand and clay, the whole being, in the latter locality, full of

* This period is represented in the Paris area by important beds of sand, rarely fossiliferous, and by beds containing plant remains, known as the Grès du Soissonais. In the Belgian area the Yprésien superiéur and the Parisélien are thought to be of this age.

† Geol. Mag., April, 1879, p. 148. Quart. Journ. Geol. Soc., xxxv., p. 209. 
lignite and without distinct fossils. In the Whitecliff Bay section their equivalents are probably beds 6,7 , and 8,123 feet thick. I have, after some difficulty, traced all the other beds separately across to the mainland. Nos. 19 to 21 in the section, almost unfossiliferous everywhere, and composed of dark laminated clays, occupy the coast on each side of Poole Harbour, and extend far inland, where they are dug into for brickmaking. Beds 22 and 23 , dull-coloured sands, with white and greyish clays, and beds of hard sandstone, represent the great mass of fossiliferous strata, from a little east of the rise of the cliffs at Poole Harbour, to beyond Bournemouth. Bed 24, 98 feet thick, composed of dark sands, clays and lignite, represents the Lower Marine series of Boscombe, which extends thence to Hengistbury Head. Beds 25 and 26, sands 147 feet thick, which are by far the most brilliantly coloured of the whole series at Alum Bay and contain only scattered layers of large pebbles, represent the Boscombe Sands or white sand and shingle of Boscombe and Hengistbury Head, where the only colours they possess, even at the Head and nearest to Alum Bay, are black, chocolate and white. Bed 27 of tough, blueish clay, with lignite, 71 feet thick, seems to represent the Hengistbury Head Clay with ironstone. Bed 28, yellow, white and ochreous sand, 41 feet thick, agrees very well with the Highcliff sands capping the headland, and which $I$ have traced across to the base of Highcliff.* The Bovey Tracey beds resemble exactly, and in every respect, the Bournemouth beds in certain places, except that the thick beds of lignite are absent. Their flora is so identical, not only in species, but in their mode of preservation and grouping, that were specimens mixed, they could not be re-separated. The so-called Upper Bagshot Beds of the London Basin are white sands which overlie the Middle Bagshot sandy clay with green grains, just as they do at Boscombe, and are in no way distinguishable from these. To connect them with the far younger Upper Bagshot Sands, we have to dispense altogether with the Upper Brackleshams and the Barton series, and to unite them with a series they do not resemble generally.

\section{The Upper Bagshot Beds.}

1. The Barton Beds.-These are well-developed at Alum Bay, being 250 feet thick, but are even better represented on the main-

* See Quart. Journ. Geol. Soc, l.c. 
land where their full thickness, 285 feet, and sequence is seen between Highcliffe and Hordwell. They are supposed to be present in the Whitecliff Bay Section, but in the absence of distinct fossils, it is doubtful whether they extended so far east. The deposit is an extremely local one, and cannot be traced beyond the places mentioned.

2. The Upper Bagshot Sands.-At Alum Bay these are pure white glass sands without organic remains, which suddenly succeed the Barton Clay. Their thickness cannot be well ascertained, and has been estimated by Prestwich at 100 feet, and by Bristow at from 140 to 200 feet. At Whitecliff Bay their position is occupied by 202 feet of yellowish sands, in which a few casts of marine bivalve shells have been seen. At Hordwell, on the opposite coast, they enclose clays containing marine shells of Barton species. Sands in the London Basin, which more probably belong to the Middle Bagshot have been correlated with these. Such a sudden succession of sand to clay involves no great physical change as apparent from Godwin Austen's researches in the English Channel. He has shown that the deposition of sand is not by accumulation on one spot, but by outward distribution." "In great sand-plains at the sea bottom, the particles brought down are drifted on over the horizontal surface, till they reach the edge of that quality of sea-bed ; they then fall over the slope, and are beyond the combined action which has moved them along. In the deeper sea sand-beds, ***, the formation of a single stratum may be continued until the effect of its accumulation ***, admits of a new bed being formed above it; so that the interval of time between one stratum and another in this zone may be very great." The necessary result of this mode of deposition by addition outwards is, that the sand zone overlaps other sea deposits, and a vertical section of a deep sea channel would often present ooze or mud suddenly succeeded, as we have it in the present instance, by clean sand. Mr. Godwin Austen also points out that, whilst on the English and Irish sides of the Channel, black mud-beds are forming in 90 fathoms, there is an area on the French side of clean siliceous sands, with a continuous extent of surface equal to two-thirds the South of England, which suggests comparisons with the sands of the Bagshot Series.

* Quart. Journ. Geol. Soc., 1849, p. 78, 79. 
The Upper Bagshots are represented in France by the Sables Moyens and Grès de Beauchamp, and most probably in Belgium by the Bruxellien and Laekenièn systems. In that case a slightly greater percentage of Bracklesham species existed in the Barton seas orer the Belgian area than in England.

\section{The Upper Eocenes}

Overlying the Lower and Middle Eocene deposits, is a series of strata of fluvio-marine origin, 560 feet thick, in the Isle of Wight. They have usually been considered Eocene by English writers, but are treated on the Continent as Eocene, Oligocene, and even, in their upper stages, Miocene. This upper series has been so ably described by Edward Forbes, that although 20 years have elapsed, little remains to be added. The Upper Bagshot Marine Sands are succeeded at the west corner of Alum Bay by fresh-water beds, abounding in fossils, known as the Lower Headon Beds. The Middle Headon Beds are dark sandy clays, with marine or estuarine shells, and the Upper Headon Beds are like the Lower, purely fresh-water limestones. It is remarkable that, during the whole of this period, there is a relatively greater development of fresh-water beds in the west of the Island and marine beds in the east. Thus, the Lower and Upper Headon Beds, which are fresh-water, are 85 feet and 67 feet thick at Headon Hill, 44 feet and 31 feet at Whitecliff Bay, whilst the marine Middle Headon is only 30 feet thick at Headon Hill, and 100 feet at Whitecliff. The nature of the beds also differs, and we see that the purely fresh-water conditions required for the formation of this description of limestone, did not during the Headon period extend so far east as Whitecliff Bay. The Headon Series at Hordwell is the only representative of the Upper Eocenes on the main-land. All the other and overlying divisions are strictly confined to the Isle of Wight, and are even there seen to occupy a progressively circumscribed area. The next strata, 100 feet thick, are composed of variegated fluviatile marls and limestones, and are known as the Osborne Beds. The divisions are, however, purely arbitrary, being merely, as is often the case, founded upon the presence or absence of certain species of shells.

The Bembridge Limestone follows, about 25 feet in thickness. At this period the peculiar fresh-water conditions required for the for- 
mation of such limestones as those of the Headon Beds had travelled east to Whitecliff Bay, whilst the synchronous limestone of Headon Hill was formed under sub-aërial conditions. The Bembridge Marls succeed, 70 feet to 90 feet in thickness. They everywhere indicate fresh-water deposition, except at Whitecliff, were they are partially marine, or, at least, brackish water. In the Bembridge Marls occurs a remarkable bed of bluish septarian stone, strongly resembling the harder insectbearing limestones of the Purbecks. Although unfossiliferous at Whitecliff Bay, where it is well exposed, it has yielded at Gurnet Bay the series of insect and regetable remains collected by Mr. J. A'Court Smith. The Hempstead Beds close the series, and are the newest beds ascribed to Eocene age in England. Lithologically and palæontologically they cannot be distinctly separated from the under-lying Berabridge Marls. They consist of $150^{\prime}$ of fresh-water marls, capped by $20^{\prime}$ marine beds. In the former occur plant remains.

Attempts have been made by many both in England and abroad, to correlate these fresh-water deposits with those of Western Europe. They can, through their fossil remains, be proved, without much difficulty, to be more or less contemporaneous, but no very exact correlation is possible where beds have been deposited by entirely local agencies.

We learn from M. Hébert's writings that a whole group of Eocenes in France and Belgium below the beds equivalent to our Thanet Sands, and of which we have no record in England, were deposited in an area alternately sea and dry land, subject to much oscillation. In the intervals between these recurring changes of level, deposits were formed, but with each they suffered much denudation, so that only fragments of the beds now remain. The deposits were formed, he supposes, by a gulf opening into the North Sea communicating with the ocean between the Shetland Isles and Norway. This sea may bave penetrated over portions of England, and left deposits upon the much eroded Chalk, which denudation subsequently carried away. However this may be, there can be no doubt whatever that the Thanet Sands, which possess a shallow-water marine fauna of remarkably temperate aspect, considering their Eocene age, were littoral deposits of the same sea, and mark a period of depression in the London Basin. 
The marine deposits of the Eocene in England are of two distinct origins, one of a Northern and the other of a Southern Sea. To form an idea of the relative position of these two seas, it will suffice to suppose that the English and St. George's Channels were dry land in these remote times, and to distinguish respectively the seas on each side of the barrier thus formed as Northern and Southern. One would include in its area the Bay of Biscay and the other the North Sea. Heer's map of Europe in the Miocene time enables us to realise the positions they occupied, and shows us that they were then still separated by land.* Not only are the faunas of these two seas very distinct, but the lithological characters of the deposits generally suffice for their identification.

Next in age to the shallow-sea deposits of the Thanet Sands of the east of the London Basin are the English mottled clays of the Western area, of fluviatile origin, which are classed with the Woolwich and Reading Series. In the direction in which they are deposited and thin out, we have the first evidence of the presence of a great river flowing from $W$. to $E$, and scouring and draining a granitic country. In the estuarine beds with lignites around London, belonging to the same series, we can trace its delta, whilst the marine sands in the east part of the London Basin are seen by their Mollusca to have been thrown down by the Northern Sea, into which it flowed.

Among the fluviatile forms met with are Cyrena, Melania, Melanopsis and Cerithium, indicative of warmth, while the marine shells are, according to Prestwich, of a more temperate climate. Turning to land evidence, the leaves obtained from Reading were submitted to Hooker, $\uparrow$ who considered that they probably indicated a climate similar to that of Fingland at the present time; but that analogous forms could also be produced from Indian or from other floras. De la Harpe + supposed that they belonged to a warm, but not a tropical, climate. Although the absence among them of any remains of a decidedly tropical vegetation is no certain indication that the climate was temperate, since there are no palms or other tropical-looking plants in many of the leaf patches of the Bagshot Beds ; yet I am inclined to think, from a consideration of

* "Tert. Flora der Sohweiz.," Vol. iii.

+ Quart. Journ. Geol. Soc., pp. 88 and 163, pl. 4.

$\ddagger$ Bull. Soc. Vaudoise, V., p. 123. 
those obtained at Newhaven as well, that the climate was as temperate at least, as the Mediterranean flora of the present day.

It is very singular that we are able to trace throughout the whole Eocene time the presence of this great River, which receded and advanced, and changed the direction of its outfall in obedience to the continued oscillations which this part of its course experienced; and we cannot help noticing how frequently marine conditions predominate in our eastern area, fresh-water in the western.

The next movement at the close of the Woolwich and Reading Beds was probably one of slight upheaval, during which the south-east of England became land. Depression followed, and the Northern Sea gradually reoccupied the tract. The masses of shingle and sand banks of the OLDHaven BeDs mark this change and are the result of the littoral conditions which prevailed during the recession, but rearranged and also greatly added to by the next advance of the sea. The remarkable extent to which the flints are worn shows that the duration of these conditions was very considerahle, whilst the change in the fauna seems also to indicate a great lapse of time between these events. In some places rolled pebbles of the Mottled Clay are included.

In the London Clay we see a further considerable depression of the land, enabling the Northern Sea to encroach gradually from the north-east, and ultimately, once only to reach as far west as the present borders of Dorsetshire. From palæontological evidence it appears never to have attained more than a few fathoms in depth in the western area, ${ }^{*}$ and a little more than 100 fathoms in the deeper eastern parts. Throughout its deposition the subsidence of the sea bed must have been quiet and gradual. The marine fauna, al though still seen by comparison with those of succeeding beds to be relatively temperate-looking and to belong to the Northern Sea, $\uparrow$ has a far more torrid aspect. This is owing to a warmer period having

* In the Bognor Beds at Alum Bay deep-sea Mollusca are absent, while their most characteristic and widely-spread genera form a group indicating marine waters of very moderate and tolerably uniform depth (e.g. Pinna, Vermetus, Calyptræa, Panopœa, Pholadomya, Turritella, etc.). These beds in the Hants basin were deposited in a shallow and open sea, not often attaining a depth of 30 to 40 feet, and averaging more probably 10 to 20 . Prestwich, "Quarterly Journal, Geol. Society," 1846, p. 237.

+ Although the abundance of Nautilus seems at first sight to contradict this, it is not anreasonable to suppose that extinct species may have existed 
set in, produced probably by the rise of land between England and North America which, there is evidence to show, took place about this time, and completely shut off the cold Arctic currents. The temperature of the sea thus increased, doubtless acted upon the land, and enabled a tropical and most luxuriant and varied fauna and flora to migrate thither and become established. Myriads of fruits and seeds, and the bones of many species of turtle and crocodile, whose habits would cause them to be buried in such a position, as well as of suakes, birds, etc., are found at Sheppey, just as they were stranded and buried in the delta-mud of the great Western River.

This sea had a considerable extension N.E., but none S., whilst the land probably stretched into warm latitudes. The London Clay marine fauna is strongly contrasted with that of the immediately succeeding fauna of the Southern Sea, by the abundance of cephalopods and the absence of corals, whilst few species of Mollusca are common to them. Prestwich inferred that this sea was extensive from the width and depth of the London Clay, "which, with a maximum thickness of 480 feet, exhibits a transverse section of 200* miles, conditions which could hardly have obtained without a large river, and, therefore, a large adjacent tract of dry land," the large quantity of organic remains derived from the land indicating the proximity of a tidal river." The estuary of the river was at Sheppey and extended to Woolwich, Upnor, Boughton, where brackish conditions are "evidenced by the great and sudden abundance of Melania and the several species of Cyrena." Its powerful fluviatile action "swept down into this Eocene sea the vast argillaceous sediment, with its rich stores of land plants and marine animals forming the London Clay."

The depression of the S.W. of the London Basin which brought in the sea, was succeeded by a slight elevation in the same direction, which caused it gradually to recede. As the water shallowed, the clay deposited became more and more sandy, and at the top of the London Clay we find sand or loam. The thick beds of sand at Alum Bay, which overlie the Clay, and form part of the series,

in somewhat more temperate waters than the two surviving species. When their presence in any formation appears to necessitate a sea temperature different in degree to that required by all the rest of the Mollusca as a group, the conclusion becomes a natural one.

* Prest., "Quart. Journ. Geol, Soc.," Vol, vi, 279. 
may represent a very great lapse of time, for it is well known that a very considerable break may occur in a series of loose sandy strata, and yet there may be no physical evidence of the fact.* Instances of this may be observed in the Bournemouth cliffs and sections wherever they are capped by Drift.

The River, whose delta was hitherto in the eastern area of the London Basin, seems next, owing to a depression to the south, to have shifted its course in that direction. Its mouth, therefore, may, during the succeeding period, have been on the since denuded Wealden Area, or still further off in the present English Channel, and we have no trace of its actual position, until it was still further deflected to the S.W. by the subsidence which later permitted the inroad of the Bracklesham Sea.

The Lower Bagshots, such as we have them at Alum Bay, Studland, Corfe, etc., were formed by river action, in a wide valley and shallow lake, and show no proximity to the sea. The complexity of the stratification suggests that two rivers united in this valley, and shows plainly that the waters must in any case have been rapid at times, and subject to periodical fluctuations of volume. We see by the composition of the Western fresh-water beds, that a granite area was still being worn away, as in the older Woolwich and Reading Beds.

As there are no passage-beds or signs of any delta having existed here between the London Clay and Lower Bagshots, it may be concluded that the river did not immediately occupy this part of the land left dry by the retreat of the London Clay sea, but flowed over it, perhaps long subsequently, having gradually shifted its outfall from $E$. to $S$. and $W$. The great deposits of rolled flints above the London Clay in the eastern parts of the London Basin, show that the Northern Sea, littoral at this period, again occupied that area for an immense length of time.

We gather from the absence of lignites in some parts of the series that there were, in the upper parts of the river, lakes such as those of Bovey Tracey, to be presently alluded to, which intercepted drifting timber; its abundance in other beds marking

* Example :-In a railway section at Clermont the Lower Tertiary sands and pebbles are overlaid by drift sands and pebbles. There is an apparent liaison between the oldest Tertiary beds and the bed of diluvial pebbles and the sandy alluvium which covers the whole.-D'Archiac, "Bull. Soc. Géol. de France," 2me sér. vol. ii., p. 341. 
the time when these had been filled in. The total absence of flint shows that the western Chalk-hills were not yet raised into position for denudation.

Heer, a long while ago, pointed out that the flora contained in the Lower Bagshots of Alum Bay formed a similar group to that of the London Clay.*

In the Bournemouth Beds we have deposits of the same river, but in a more open and level valley, and in closer proximity to the sea. In all the lower or freshwater series we have no sign of the presence of sea-water, and when we do find it in the higher beds to the east, it is not that the river deposits encroached there on the sea, but that the land gradually sank, and allowed the sea to cover them.

It is of great interest to trace through these beds the change from a comparatively upland flora, to a valley, and then to a swamp flora ; to follow out the lowering of the land until it became sea; to trace the sea, first trickling in as it were, and forming lagoons, then overwhelming the mud deposits formed by these lagoons, with shingle and sand; to realise in fact the actual shore line, now marked by river deposits full of plant remains on one side and a sea fauna with shark's teeth on the other.

The series of marine beds from Bournemouth to Higheliff, which belong to the Bracklesham beds, are the shore deposits of the Southern sea. The Bracklesham Series proper show a gradually deepening sea; for, while the beds of sand which are prevalent in the lower stages show shallow water, the clay beds above them were formed in a deeper sea, and contain deeper water Mollusca. In comparing the marine fauna with that of the London Clay, its very much more tropical character is apparent. Many southern types of Mollusca abound in it which are scarcely represented in the London Clay. Their aspect is completely different, and though separated geologically by but a short interval of time, hardly any spesies are common to both, while the lithological characters of the formation are widely and persistently dissimilar. If we examine, on the other hand, the terrestrial fauna and flora of these and the intervening strata, we see that no increase of temperature or change had taken place in the clinate, and that the land was still inhabited 
by similar groups of reptiles and plants. It is therefore plain that the sea alone had changed, and become much warmer, for depression had enabled the Southern Sea, then occupying part of France, to advance and to overlap to a small extent the older deposits. The same depression diverted the embouchure of the river towards this area, and its influence is discernible in the Bracklesham Beds, whose shallow sea bottom was subject to drifting water. The Rev. O. Fisher, ${ }^{*}$ remarking upon these facts, says: "The shells in such beds are often drifted into patches, while a few yards off scarcely a specimen will be found;" and, again, that " many of the beds are laminated, being composed of alternations of very thin bands of clay, separated by sandy layers. Such are generally devoid of shells, but contain much vegetable matter. They appear to have been caused by the deposit of sediment, in a quiet estuary from a great river, the changes to the coarser sediment being caused by the state of the flood."

During the whole Eocene period till the time of the deposition of these beds, the now separate Tertiary basins of London and Hampshire were continuous, and similar series of strata were deposited over them. Thenceforth, however, it is clear from the absence of any of the newer Eocene deposits in the former, that they had in some measure become severed. The London Basin must have been upheaved at the close of the Middle Bagshot period, and we lave no evidence that it was again depressed, although it has since been subjected to denudation on a large scale. $\dagger$ The depression which lasted throughout the Bracklesham period was prolonged into that of the BARTON BEDs, which are found to indicate still deeper seas. A remarkable change in the fauna almost suddenly took place. We see an influx of Mollusca of a comparatively temperate aspect, recalling strongly those of the London Clay, nany of the species which had disappeared in the intermediate Bracklesharns, reappearing in the Barton series.f At the same time there was a migration of the more tropical of the Bracklesham

* "Quart. Joum. Geol. Society," 1861, p. 67.

+ It has been estimated that the "vertical loss in the Valley of the Thames is 500'," and that " the tlat arch of the Isle of 'Thanet is not wholly owing to the Chalk having been thrown into that form, as at least $600 \mathrm{ft}$. of other formations have been denuded off that tract."- "Memoir of the Geol. Survey," Vol. iii., p. 55.

$\ddagger$ See Presiwich, "Quart. Journ. Geol. Society," Vol. xiii., p. 131. 
forms, including all the larger cones, cowries, bullæ, cerithia, the great cardia and nummulites, only 25 of the least tropical looking Mollusca remaining to mix with the new fauna. This can only be explained by the mingling of the waters of the Northern and Southern seas, due to the temporary submergence or destruction of the dividing isthmus, which we know had already become extremely narrow, since deposits of the older seas actually overlapped each other in the Isle of Wight. The succeeding UPPER Bagshot SANDs belong to the same period, and, as already remarked, do not necessarily indicate change.

After this the seas were again severed, and remained so until recent times; the English Channel, there is reason to believe, having been indeed formed during the human period.

The whole of the vast overlying fluvio-marine UpPer Eocene, or Oligocene series, more than $500 \mathrm{ft}$. thick, presents us with the section of a great river delta formed in an area of depression, simflar perhaps, to that of the Nile, or Ganges. Each successive estuarine deposit seems to have been thrown down over a more and more circumscribed area, and by a diminishing volume of water. The lowest, or Headon Beds, alone can be traced across to the main land; whilst the highest, Hempstead Beds, are almost confined to a single hill. These enormous accumulations present us with the record of an unbroken series of events in one spot; extending from the Middle Eocene to perhaps the Miocene age in Europe. During this lapse of time we see constant changes and modifications taking place in the Mollusca. Over and over again fresh species of Cerithiadæ, Linnæidæ, Melaniadæ, and other estuarine shells come in and disappear again. The muddy flats swarmed with these Mollusca, and the banks seem to have been clothed with ferns, reeds and palm's. Mammalian remains abound in places throughout the whole series, but even more numerous are those of turtle, gavial, alligator, and crocodile. In the Bembridge Limestone capping Headon Hill, we have an actual subaërial formation, remarkable for the immense number of shells and eggs of large tropical pulmonate Mollusca which it contains, implying an extensive and adjacent land flora. During this period, too, we not only have evidence of the diminution of the volume of the river and final silting up of the estuary, but also of a gradual lowering of the temperature; and, consequently, a more and more wide 
departure from the tropical conditions which prevailed during the Middle Eocene, and extended to the close of the Headon period. At last the diminished river, in the cooler Hempstead times, left the country swampy, and covered with rush and water plants.

From the close of the Hempstead period until the river finally became lost, its delta or embouchure may probably have lain in the Solent Channel or in the sea beyond, as there is nuw no trace of it existing.

The truly marine Mollusca of the highest Hempstead bed appear so impoverished and present such a pancity of species, and these so stunted, that, coupled with the nature and limited area of the deposit, we must conclude that they were formed in a sea which had shrunk to a mere salt or brackish lake, without communication with the open sea beyond. That it was completely isolated is certain, since there is no incoming of the Miocene marine forms which existed abundantly elsewhere. The forms are characteristically Eocene, but, except such as the Corbula, which were apparently enabled to withstand the infux of fresh water, of a degraded type. We have no evidence of the Hampsbire Basin again becoming submerged; and, although there are abundant indications of larger rivers than those at present existing having flowed through the district even in human times, how far, or whether they were in any way connected with the great waters whose history I have endeavoured to trace, is very doubtful. Nor have the oscillations which produced these frequent changes of level, and at a later period upheaved the Chalk, altogether ceased, as there is abundant evidence in the Isle of Wight, and on adjacent coasts, of elevation and subsidence even in Historic times.

It is interesting to find that Mr. Sorby, now President of the Geological Society, inferred on totally independent grounds - the study of evidence of wave and ripple action in the marine and estuarine beds of the Isle of Wight-that a great river ran from the west into the sea, its estuary including part or the whole of the present Isle of Wight, and that the breadth of its estuary was there 15 or 20 miles. "Yet the dimensions of the river were such as to keep the water in general more or less fresh, and must have been much greater than any now running in England." He was able to trace the approximate size and dircction of the shoals, and 
the axis for the rise and fall of the tides, the direction of the freshwater currents and prevailing winds, at least those which acted with most force upon the sea. This confirmation is of value.

Thus, thronghout the whole of our Eocenes, the river action may be more or less distinctly traced, and whether we examine the structure of the rocks themselves or the fossils they contain, the conclusion is irresistibly forced upon us that, for countless ages, the mouth of a great river occupied at first the south-east and then the south of what is now England, and that, during the whole period its delta was subject to change of level, becoming more or less depressed, according to the almost universal law wherever great sediments accumulate, as we see in recent deltas, permitting now the sea to invade it, now the deposits to rise above water, and become inhabited by plants and animals.

It is impossible, except by its deposits, to track the course of the river, which, for countless ages, brought down and imbedded plant remains from a western land. The upheaval of the great Chalk ridge and denudation have probably completely obliterated every trace of its former valley, which may moreover have lain where now is sea. At Bovey Tracey, however, there is what appears to be an exceedingly interesting relic, marking the site of what was perhaps formerly a lake, into which it flowed in its course. This is a great basin, of what has been hitherto supposed a perfectly isolated Miocene deposit. I have ascertained, however, on palæontological evidence, that the series is contemporaneous with the Eocene at Bournemouth. This lake, which we see silted up, lies in the direction whence the river came, and must either have been in its direct course or in that of one of its affluents.*

It is not improbable that remains of other lakes may yet be

* Lyell's account of the imbedding of plant-remains in the Slave Lake, is curiously like what mast have happened here:--." In Slave Lake in particular, which is $200 \mathrm{~m}$. long, the quantity of drift timber brought down annually is enormous." The trees become water-logged and sink, and "the trunks gradually decay, until they are converted into a blackish-brown substance resembling peat, but which still retains, more or less, of the fibrous structure of the wood; and layers of this often alternate with layers of clay and sand." The banks have " a remarkable horizontal slatey structure" (along the Mackenzie), and display almost everywhere horizontal beds of woody coal, alternating with bituminous clay, gravel, sand, and friable sandstone. * * * The Slave Lake itself must, in process of time, be filled ap by the matters daily conveyed into it by the Slave River."-" Principles of Geology," loth edit., 1868, vol. ii., p. 526. 
found in Cornish or Devon valleys. These very lakes may, as already mentioned, by intercepting the drifting timber, have caused the otherwise curious absence of lignite in most of the Bournemouth beds, whilst its abundance in later beds may furnish a clue as to the time at which they became completely filled in.

Having traced the probable existence, for countless ages, of a river of far greater magnitude than any which the drainage of our present England could furnish, and coming from the west, the question arises as to what could have been the extent and position of the land-surface from which it flowed.

In the first place it is certain that the beds were not deposited under Archipelagic conditions, like those under which it is supposed the Miocene Beds of Central Europe were formed, for great rivers are not found in Archipelagos. Again, independently of the physical evidence of the volume of the river, the plant-remains already known indicate the former existence of floras so large and varied that we cannot but believe that the land-surface upon which they grew, must have been of Continental dimensions.

Most of us are probably familiar already with speculations as to the former existence in the Atlantic of a Continental area. One of the earliest of these was in 1847, and due to Edward Forbes. The small Iberian flora lingering in the S.W. of Ireland, was thought to indicate direct preglacial connection with the Spanish Peninsula. He was thence led to think it possible that land might have extended into the Atlantic to beyond the Azores, and that its coast-line was perhaps indicated by the gulf-weed bank between $45^{\circ}$ and $15^{\circ} \mathrm{N}$. lat. This idea has, however, not met with support, and there are other ways of accounting for its presence. Unger* having identified fossil plants from Sotzka with Australian types, delivered in 1860, a lecture upon the "Sunken Island of Atlantis," and in the following year another entitled "New Holland in Europe." The extraordinary occurrence of American, Asiatic, Australian and African genera in all European Tertiary floras, convinced Heer as well as many others, that some communication had existed between these several lands at former times. The question has since then been frequently discussed from different points of view, as often as fresh discoveries and information have been brought to bear. For a long while all this was but specula-

\footnotetext{
* Translated in the “Journal of Botany,' for January and February, 1865.
} 
Reduced copies of Prof.Prestwich's Sections of the vertical section in Alum and Whitecliff Bays.-From "Quarterly Journal of the Geological Society," 1879, p. 226. Reprinted by permission of the Society.

Section at Alum Bay.
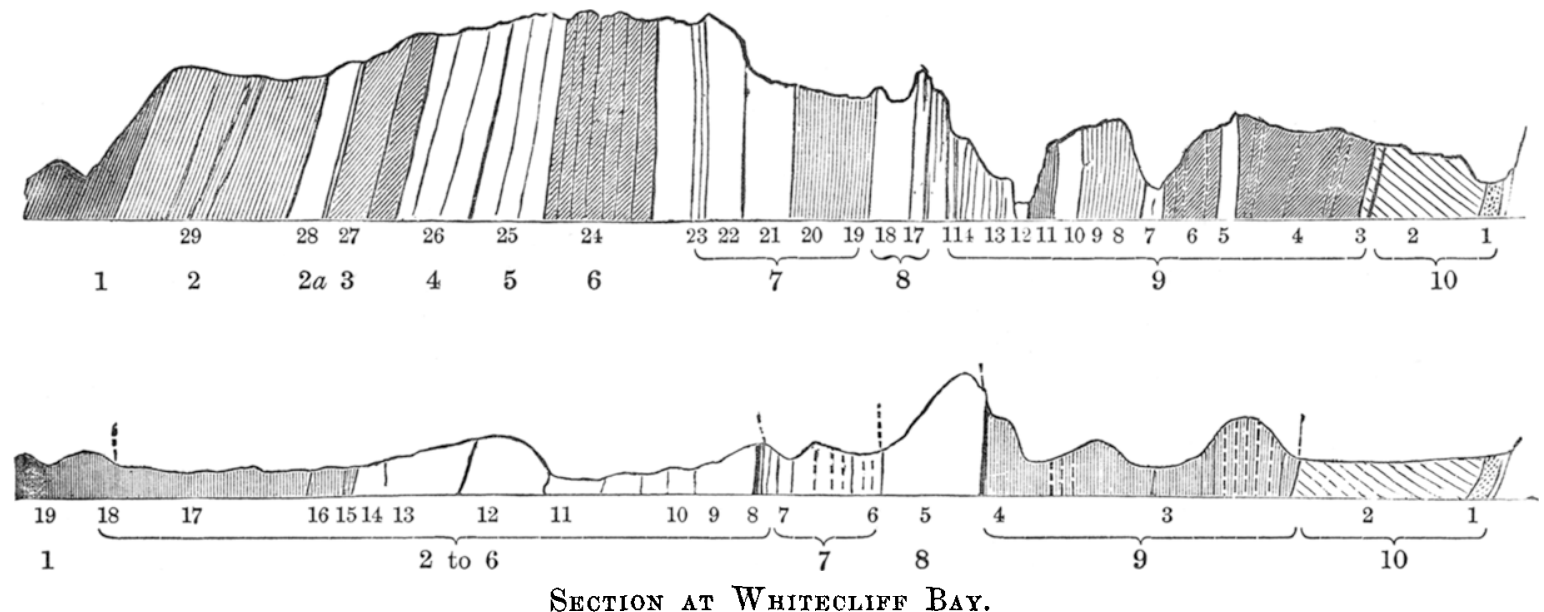

The small numbers used are according to Prestwich, the larger nnmbers accord with my new nomenclature. The dotted lines indicate the correlation of the beds. The large nnmbers correspond with those used in fig. 2.1 . The Barton Beds. 2. The Upper Bracklesham and Higholiff Sand. 3. The Hengistbury-Head beds with ironstone. 4. The Hengistbury-Head beds with green grains. 5. The Boscombe Sands. 6. The Boturnemouth Marine series. 7. The Bournemouth Freshwater series. 8. The Lower Bagshot Beds. 9. The Loudon Clay, 10. The Woolwich and Reading Series. 
tion, yet year by year those who have studied the present distribution of genera and species, whether of plants or animals, marine and terrestrial, have become convinced that in times often not geographically remote, continents and islands now separated by seas were united together. The studies of geologists, especially of those working in the Tertiary rocks, show even more conclnsively the former connection of lands now widely severed. That a different distribution of land and water prevailed, at all events in Eocene times, in our area, is no longer theory but fact, and in order to account for the leading observed facts, we have to conclude that at various times our Eocene land was connected more or less directly with very distant parts of the world indeed.

It was not, however, until the return of the Challenger Expedition, and the publication of the contour chart of the great Atlanticridges that it was seen in which lines they were possibly actually connected. This map shows that a great ridge, less than 1,000 fathoms deep, runs in a ziz-zag direction, north and south, sending off spurs which connect $\mathrm{N}$. and $\mathrm{S}$. America with Africa and Britain, or W. Europe. This faintly shadowed sunken continent, supposing it for a moment to bave once been land, is so unlike any existing land, that no one would, perhaps, have ventured to evolve so strange a shape to meet the requirements of a theory, yet it is hardly possible that any other form would have sufficed so completely to render possible the union in the Eocene of faunas and floras from so many lands. In a lecture delivered last year at the South Kensington Museum, Mr. W. S. Mitchell very clearly pointed out the bearing that the discovery of this ridge had upon past and present plant distribution.* The majn ridge still rises in four places to dry land, and soundings by the U.S.S. "Gettysburg" tend to show that Madeira also was a portion of it. From the deeper basin land also rises at Fernando de Noronha, Trinidad, and St. Helena.

Now, if we consider that since the sinking of the Eocene land many of the great mountain ranges of the world have been upheaved to the colossal heights which they now attain, we may fairly assume that compensating depression had taken place in other areas to an equal extent during the same time. Wo might thus claim that the

$$
\text { * See " Nature," April 20, } 1877 .
$$


greatest depths of the Atlantic had been dry valleys and lake-basins, with a mountain chain between them 16,000 feet in elevation, with peaks, such as Ascension and St. Panl, towering to 30,000 feet, forming a vast chain of mountains above the snow level, and stretching from an Austral land across the Equator. But a far less elevation will suffice to explain all yet seen, and the great depths may have remained ocean ever since the Chalk period, and, perhaps, for long before. An elevation of 2,000 fathoms would produce the continent, whose outline we see traced, possessing a ridge 6,000 feet high, rising here and there to 12,000, and this, or even less, would have permitted all the temperate forms we have in the Eocene to have passed right across the Equator. An elevation of less than 1,000 fathoms would unite England and Ireland, and extend the land far west, 600 miles beyond Cornwall, producing an area sufficient to account for the magnitude of the river. I would limit the supposed elevation to the minimum that will explain the facts, because there are no oceanic Eocene deposits known, although vast strata, similar in extent to the Chalk, must have been then, and are now, uninterruptedly forming. It may be supposed these have been brought to the surface and again have sank, for it is certain that areas of sea, contiguous to both Europe and America have been land at no distant date, and the present zoological and botanical distributions make it almost equally certain that great tracts of the bed of the Atlantic were also land.

There is no need, however, to suppose that the whole of the connecting ridges were above water at the same time, or even that the Southern and Northern areas were ever actually connected by nubroken land. The ridge may have been severed from the most southern lands, for example, in the remoter Cretaceous times, and submergence, commenced in the south, have progressed gradually north, giving rise to elevation in front of it, upon which the plants imperceptibly travelled. However the Australian plants, for instance, crossed the Equator, whether by way of Asia, Africa, or the Atlantic, it seems that the bridge hehind them became submerged, since the indigenous Australian flora and fauna remain almost unmixed in their original habitats. It is curious that the types derived from this particular flora never reached America, and must very early have ceased to exist in Europe, since scarcely any remnant exists in our present flora. 
The incoming of American types appears to take another instance, of later date than that of the Australian. In America an almost unbroken record of the land vegetation exists from Cretaceous to Miocene, or even Pliocene times. The lower portion of this sequence is supposed to be older Cretaceous, and although the evidence of such great antiquity is not conclusive, yet it is much older, at all events, than any of the Eocenes. It contains a flora, differing essentially from any other known flora, and which was evidently a completely isolated one. Although principally composd of dicotyledons, and, therefore, eminently Tertiary, it is associated with Dinosaurians, and a fauna largely composed of Cretaceous types. This older flora is rather suddenly replaced by an Eocene flora of European type, including palms and other plants, which appear not to have previously existed in this part of America. The rise of temperature, simultaneously with the incoming of a fauna and flora, in part at least European, taken together with an obvious rise in temperature between the Thanet Sand and the London Clay, and the subsequent appearance in the Bournemouth, or Middle Bagshot, of a preponderance of American plants, seems to fix conclusively the date as Eocene, of that rise of land to the North, which united Europe and America, and permitted the floral types to mingle. This connection alone, by shutting off the Arctic currents, wonld have converted the North Atlantic into an ocean, locked in by land W., N. and E., bounded on the South by the heat of the Equator and in great part nnder the rays of a tropical sun. These conditions are calculated to produce the hottest climate in the world.

It is probable that throughout the whole of the Eocene period this land was slowly sinking. The great submergence, however, did not take place until Miocene times, and its enormous mass must have at least helped to cause the elevation of the Alps. The magnitude of the subsidence may be inferred from the mass of the eleration. While the London Clay was forming, Lyell points ont, the sea still rolled over some of the loftiest summits of the Alps, and the changes that have subsequently occurred equal in amount the conversion of sea into a continent as large and lofty as that of Asia, Europe, and North $\Lambda$ frica, and of land into sea to at least an equal extent. "The grand sinking down of the conglomerate of the Molasse, more than a mile vertically, 
did not begin till all the Eocene movements had terminated, and the upheaval of the same Molasse took place at a later period, so. that it reached at length its present altitude of 3,000 or 4,000 feet above the sea." * In face of such stupendous movements, the oscillations in England were insignificant, the total sum of the depression here in Eocene times not exceeding 1,800 feet. Our area was but the border land, the axis between elevation to the east and subsidence to the west, and although continually shaken, participated decidedly in neither movement. Results of the forces which acted are to be seen in the vertical beds, and the contorted strata on our sonth-western coasts arond the Isle of Wight, for the general direction from South to North of the folds of the Chalk is evidently the result of lateral pressure, and not the direct action of local forces.

My work has led me to the belief that throughout the whole Eocene Period a vast river flowed from the westward, from an area now so reduced in size that it would now support but comparatively small streams. The discovery of the abundance and variety of the flora brought down by it, together with the evidence we possess from the difference of the fauna of the Eocene seas in portions of their basins now dry land, that at that time the North Sea and the Bay of Biscay were as completely severed as the Atlantic and Pacific, and tend to confirm theories leading in the same direction, put forward formerly by many and independent workers.

\footnotetext{
* Lyell. "Annirersary Address" to the Geological Society, I850.
} 
Proc. Geol. Assoc., Vol.vi. Pl. 1.

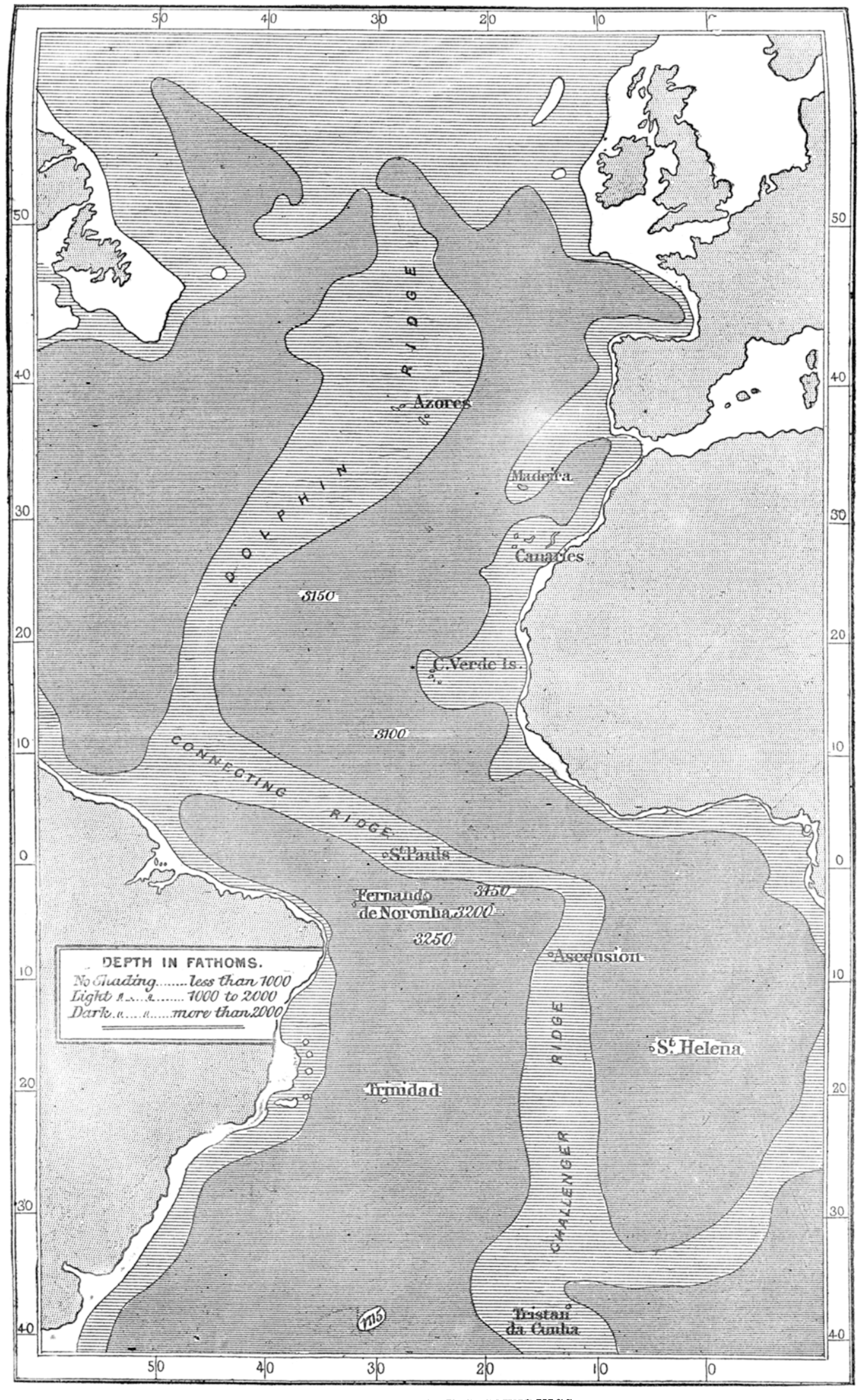

CHART OF ATLANTIC SOUNDINGS. 